\title{
2. Researching Identity Constructions
}

Rachel Reckinger, Christian Wille

\subsection{A thEORETICAL-CONCEPTIONAL APPROACH TO IDENTITIES}

\section{Identities in Luxembourg}

This book is about identities in Luxembourg. The choice of the plural form already indicates that it has not been our aim to define once and for all a 'national identity' or to establish what makes up a 'typical Luxembourger'. Instead, our focus has been on the processes of identity formation and their modes of expression empirically accessible to the researchers at different levels. So why choose 'Luxembourg' as the investigative context for examining identities? Or in other words: What makes Luxembourg interesting for studying identity construction? To approach this question we first have to clarify the process of de-traditionalisation and its effects on identities and subsequently consider some specific features of Luxembourgish society.

In the research community the concept of identity is interpreted in a variety of different ways. As will be shown later, these can be classified by different criteria, which already brings us to a characteristic feature of the 'identity question': the attempt to produce order(s). Such attempts to create some kind of order use categories either attributed or rejected by themselves or by others that characterise very specific (group) affiliations. These can refer to, among many other things, regions, nations, occupations, family, gender, and aesthetic styles by the means of which the identity options circulating at different levels are 'processed'. However, such processing has become more complex due to ever increasing differentiation, individualisation and pluralisation of societies. These keywords sum up the process of de-traditionalisation, which challenges what are perceived to be the traditional parameters of identity. In effect, this means a relativisation of what is considered normal or taken for granted through an augmentation of identity options, resulting from the global circulation of commodities, images, symbols, ideas, and life styles. 
Due to the fragmentation and mixing of 'homelands', traditions and systems of meaning that provide a sense of purpose, frequently designated with the term 'Postmodernism', the notion of stable and coherent identities or orders is no longer tenable. Rather, identities are understood as something established through personal performance or as construction tasks - in terms of Doing Identity - which Eickelpasch and Rademacher (2004) as well as Keupp et al. (1997; 2006) associate with the concept of "Identitätsarbeit".

Identitäten gleichen in einer zerrissenen Welt der Spätmoderne nicht fertigen Behausungen mit einem dauerhaften Fundament und einem schützenden Sinn-Dach, sondern permanenten, lebenslangen Baustellen, auf denen die [...] Individuen ohne festgelegten Bauplan und unter Verwendung vorhandener Bausätze und Sinnangebote sich (bis auf weiteres) eine Unterkunft schaffen. Je nach situativem und biografischem Erfordernis sind An- und Umbauarbeiten fällig ${ }^{2}$ (Eickelpasch/Rademacher 2004: 14).

The contributions in this book take up this notion, based on the thesis that Luxembourg offers almost a laboratory setting for the investigation of processes of identity construction under de-traditionalised conditions. This touches on the pluralisation of identity options within Luxembourg society created by the manifold interdependent relationships that have evolved on a social, cultural, political and economic level, already apparent at least since 1900. For it was indeed at the end of the 19th century, with progressive industrialisation, that the first Italian and German immigrants came to Luxembourg, which had previously been an exclusively agrarian society, so that at that time already about 60 percent of the steel workers in the south of the country were made up of foreigners. Further waves of immigration - in particular from Italy - followed during the growth periods of the 1920 s and after the Second World War. The great demand for labour in the industrial sector prompted many Italian workers to have their families join them in the 1950s. The 1970s saw the first influx of Portuguese immigrants who, to this day, make up the largest share of the resident foreign population, and during this time the Italians progressively moved up the social ladder (Willems/Milmeister 2008; figures 2008).

While as early as 1970 one fifth of Luxembourg's population were resident foreigners and, with the crisis of 1973, the problems associated with immigration

1 | Personal translation: "Identity work".

2 | Personal translation: "In the fragmented world of postmodernism identities do not resemble completed dwellings with a firm foundation and a sheltering roof of meaning, but rather permanent, lifelong building sites on which the [...] individuals erect - without a specific building plan and making use of any available construction kits and choices that offer sense and meaning - a (temporary) domicile for themselves. Situational and personal needs might necessitate further extension and rebuilding works" (Eickelpasch/Rademacher 2004: 14). 
increasingly came into focus, the cross-border workers from the neighbouring regions of Saarland and Rhineland-Palatinate, Lorraine and Wallonia entered the picture. Until the early 1980 s, their proportion of the workforce was still less than ten percent; in the course of the rapid development of the service industry that followed the heyday of the iron and steel industry their numbers grew explosively in the 1980s: in 1990 cross-border workers already constituted twenty percent of the workforce; in 2009, 147,000 Germans, French and Belgians made up almost half of the workforce in the Grand Duchy.

In addition to classical immigration and cross-border worker employment, the Grand Duchy has for some years also seen a strong increase of highly-skilled personnel. In general they tend to hold executive positions, either sent abroad by their companies or coming to the Grand Duchy as international corporate nomads'. This highly mobile group, which includes managers of international companies as well as EU officials, is recruited for the most part from European countries. At the most important location of Luxembourg's EU institutions, the Kirchberg plateau in downtown Luxembourg, developed during the 1960 s, and at other locations in the south and centre of the town, for example, 11,000 people work for the EU administration (Chilla 2009). A large number of highly qualified personnel are also employed in the commercial sector, particularly in the financial industry: in 2008, four fifths of the executive workforce of the Banque Centrale de Luxembourg, for example, were foreign residents (Fehlen/Pigeron-Piroth 2009: 6). Already in the 1970s, the financial sector superseeded the iron and steel industry that had dominated until then and has, at least since the 1980 s, influenced also other industries. Thus, the service industry in the Grand Duchy saw an impressive boom and the society, which had already transformed from an agrarian to an industrial one, underwent in a short time a virtually unprecedented and radical process of change towards becoming a tertiary economy.

Today, the presence of highly qualified personnel from across the world, including the EU officials, has perceptible effects in Luxembourg. They lend an international character to the country, in particular the capital, which is by far more cosmopolitan than other European towns of comparable size. Furthermore, English is becoming increasingly significant alongside the usual languages French, German and Luxembourgish, particularly in the international financial sector and in developing expatriates communities (Fehlen/Pigeron-Piroth 2009: 6). As a consequence, what the region now has to offer in terms of cultural activities is very varied and multicultural, even if the major event "Luxembourg and Greater Region - European Capital of Culture 2007" succeeded only partially in elevating the Grand Duchy above its 'avant-garde provincialism'. In addition, the city management of the city of Luxembourg is making efforts to integrate the famous UNESCO world heritage into the daily life of the inhabitants and to enhance the awareness for it among tourists visiting the region; the country's museums and new decentralised cultural facilities are providing an environment for the growth of a critical intellectual mass. The Minette region in the south of the country is currently 
undergoing substantial changes thanks to cultural upgrading, the establishment of service enterprises and the forthcoming relocation of the university of Luxembourg to the site of the former brownfield of Esch-Belval, which will see an architectural marriage of tradition and modernism. The rural regions in the north, the west and the east of the country are also implementing future-oriented development strategies via self-confident funding bodies and civil participation. In short: Luxembourg is undergoing profound transformations while at the same time there has been little change in the distribution of political power, which reflects another specific feature of the Grand Duchy.

As an outlook to the following chapters, this tour d'horizon already indicates that Luxembourg is a place that generates multiple and continuously changing identity options. Besides other distinct features of Luxembourg society, three particularly salient ones are the pluralism created by labour migration, the multilingual context, and international interdependencies in nearly all aspects of society. On account of Luxembourg's history, geographic location and limited size, all these features already have an inherent transnational dimension. Thus, Luxembourgish society can be seen as an almost exemplary case of a 'region' within 'transnational landscapes' ('scapes'3) where traditional classification categories apply less and less. With this in mind, the following section of this introduction will focus on the concept of identity work or Doing Identity described above, in order to emphasize the fleeting and constructional nature of identities that is the point of departure of this study.

\section{Putting Identities in a Theoretical Framework}

The issue of 'identity' has for quite some time received a great deal of attention - both as a question of everyday life and as a subject of research. Even though the questions "Who am I (have I become)?/Who am I not (have I not become)?" and "Who are we (have we become)?/Who are we not (have we not become)?" (see Abels 2006; Straub/Renn 2002), which are inseparably connected, constitute an ontological constant of human reflexivity and have been documented in written evidence at least since antiquity (Keupp et al. 2006), they have attained a new significance in postmodern times. As Rosa notes: "Identität [stellt] eine anthropologische Notwendigkeit dar und keine Erscheinung der Moderne [...]. Subjekte beziehen ihre Handlungsfähigkeit zu allen Zeiten und in allen Kulturen aus ihrem Sinn dafür, wer sie sind. Allerdings wird dieser Sinn in der Neuzeit in besonderem Maße

3 I Under the concept of 'scapes', Appadurai sums up intermeshed and changeable 'landscapes' in order to describe social, cultural or economic figurations that crystallise in the course of globalisation. He draws a distinction between ethnoscapes, financescapes, mediascapes and ideoscapes (see Appadurai 1998). 
fraglich [...]"4 (Rosa 2007: 50). This advanced detraditionalisation, differentiation and individualisation of social structures in Western capitalism (Straub/Renn 2002) has led to a hightened level of self-design in all aspects of life, whose ambivalent responsibility lies increasingly with the individual (see Ahbe 1997; Bauman 1999). This personal responsibility means at the same time more freedom of choice and more room for questioning, since such individually designed lifestyles hold the possibility of success as well as failure. In other words: Circumstances such as these imply a continuing and never completed "Identitätsarbeit"s (Keupp et al. 2006; Straus/Höfer 1997) while always having to be seen as a "riskante Chance"6 (Keupp et al. 2006; Eickelpasch/Rademacher 2004).

Despite this pluralisation of possibilities of identity construction, their scope is limited by the quantity and quality of social interactions as well as economic and everyday-cultural resources - and therefore by structural capitals of social inequality (Bourdieu 1992; 1972) -, by which identity constitutes itself through mechanisms

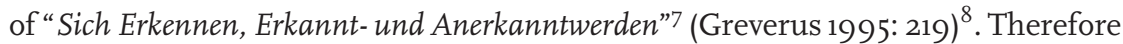
identity constructions contain a twofold ambivalence: due to eroding dependencies on predefined paths there is, on the one hand, a compulsion to make a choice, which still holds the possibility of either success or failure, and, on the other hand, there is the freedom of choice which still is socio-culturally moulded. Richard Sennett sums up this ambivalent condition in a humorous way: "In der Moderne übernehmen die Menschen die Verantwortung für ihr Leben, weil sie den Eindruck haben, es hängt von ihnen ab"9 (1996: 48).

From the 1950 s and in particular from the 1980 os onwards, 'identity' - as "das je spezifische Selbst- und Weltverhältnis sozialer Subjekte"10 (Rosa 2007: 47) -, became a central subject of research in the social and cultural sciences. The academic

4 | Personal translation: "Identity constitutes an anthropological need and is not just a phenomenon of the modern age [...]. Subjects draw their capacity to act at all times and in all cultures from their sense of who they are. In modern times, however, this sense has become increasingly precarious [...]".

5 | Personal translation: "Identity work".

6 | Personal translation: "Risky opportunity".

7 | Personal translation: "Recognising oneself, being recognised and appreciated".

8 I Identity constructions that are understood in this way relate to the "postmodern foil and therefore to processes of performance, repetition, subversion, recognition, being rooted, as a constant shift between potentialities and facticities, between differences and similarities, between variances and continua, embedded in power and knowledge structures". (Baltes-Löhr 2006: 64) To clarify this mobile complexity, she writes metaphorically: "The pattern originates while weaving" (idem: 37 ).

9 | Personal translation: "In the modern age, people accept responsibility for their life because they are under the impression that it depends on them".

10 | Personal translation: "The social subject's unique relationship with her/himself and the world". 
canon makes a conceptual distinction between personal and collective identity (see Luckmann 2007); that is to say, on the one hand, "die Art und Weise, wie sich der Einzelne als Individuum verstehen soll"11 - in developmental-psychological ${ }^{12}$ as well as historico-socio-cultural terms - and on the other hand, "die Form des Selbstverstehens, in dem sich der Einzelne als Teil eines Kollektivs definiert"13 (Reckwitz 2001: 21). This collective may be structural (e.g. gender, age, state of health, etc.), social (e.g., family, networks, milieu affiliation, employment, educational level etc.), everyday-cultural (e.g., intimacy, normative standards, values and preferences, consumption style and lifestyle, community of values such as religious communities or civic, political or leisure associations etc.), national, ethnic, etc. In everyday life, however, these spheres of experience, separated here for the sake of clarity, are closely intertwined:

L'un des paradoxes de l'identité personnelle est précisément de s'exprimer par l'appartenance à des groupes et donc par le croisement d'identités collectives (je suis un homme, libraire, père de famille, militant politique, amateur d'opéra, d'origine italienne, etc. $)^{14}$ (Halpern 2009: 13).

Nevertheless, we regard the notion of the collective within the identity discourse less as something determined by group affiliation - in a metaphor that expands stepwise and ranges, both in linear and disjointed form, from the individual via groups defined by interaction and affinity all the way to large-sized social-cultural groupings $s^{15}$ - but rather by the permanent reference to moral concepts and norms, resources and stocks of knowledge shaped by society and that guide every individual action. Depending on the subject of analysis, this individual action can be initiated by individuals or by groups. The crucial point here is, in our view, a consistent empirical registering of the "Wir-Schicht"16 (Elias 1986) in every single action, which can be regarded as an identity project - without the agents necessarily being aware of this. In this we follow traditions of research which centre primarily, on a theoretical level, on "die Balance zwischen individuellen Ansprüchen und

11 | Personal translation: "The way a person should recognise himself or herself as an individual".

12 | We will discount the developmental-psychological perspective here, since it transcends the scope of the interdisciplinarity practised by us.

13 | Personal translation: "The structure of the specific self-understanding in which the individual defines her/himself as part of a greater whole or a collective".

14 | Personal translation: "One of the paradoxes of personal identity is precisely that it expresses itself via group affiliations and therefore by mixing collective identities (I am a man, a bookseller, a father, politically active, an opera lover, of Italian origin, etc.)".

15 | Halpern 2009 or Ruano-Borbolan 1998 are an example for this approach.

16 | Personal translation: "We-layer". 
sozialen Erwartungen"17 (Abels 2006: 254; see Krappmann 2005) and do not limit themselves to the functional (multiple) affiliations (Goffman 2003; Lahire 1998) that have multiplied in postmodern times.

It is precisely in this point where our view on collective identity differs from discourses emerging from everyday life or often used to ideological-political ends, which frequently employ standardising and reifying arguments. The notion of 'identity' - particularly when used in the singular - is emotionally charged and employed in statements that tend to be rather simplistic, for instance when there is talk that a "village identity" should be protected, a "national identity" seems threatened, or when an "European identity" is evoked. 'Identity', according to this view, refers to a presumed sense of community of a group whose members are homogenised; they are denied individual possibilities of development and alternative loyalties are suppressed. They are seen not so much as individuals in their own right that share a certain commonality than as a quantitative alibi for cooptations in the name of the group. Above all however, this kind of discourse tends to refer to a supposedly naturalised essence (see Weinreich/Saunderson 2003; Reckwitz 2001), which has not been empirically verified and effectively serves as a basis for a further abstract and generalising treatment of the issue.

This social circumstance has spawned a certain scientific mistrust towards the concept of collective identity (see Kmec 2007; Kaufmann 2004; Brubaker 2001; Giesen 1999; Bayart 1996), which was held to incorporate an inherent "Tendenz zum Fundamentalismus und zur Gewalt"18 (Niethammer 2000: 625). Although one could take the view that collective identities do not exist per se (since they form no physical entities capable of language and action), their social and cultural performativity is nevertheless real (see Meyran 2008), since they are, precisely because of their "Nebulosität bestens für eine ideologische Diktion geeignet"19 (Straub 2004: 293) and, therefore, still worthy of research. This is why Niethammer re-commends "dass wir, anstatt irgendeine kollektive Identität zu beschwören, ,wir' sagen" 20 because "WirAussagen [...] vor allem in ihrer Subjektivität leichter erkennbar und dadurch diskutabel sind" 21 , i.e. they lend themselves less easily to the "Totalisierung einer speziellen Gruppe"22 (2000: 628-629). Bayart suggests speaking of identitary strategies (see 1996) instead of an 'independent' identity, MacClancy prefers "modes of identification" (2004: 64), which stress the subject-centred, relational, active

17 | Personal translation: "The balance between individual demands and social expectations".

18 | Personal translation: "Tendency towards fundamentalism and violence".

19 | Personal translation: "Nebulousness ideal for ideologically tainted discourses".

20 | Personal translation: "That, instead of invoking a collective identity, we say “we'”.

21 | Personal translation: "The subjectivity of we-statements [...] is easier to identify, making them discussable".

22 | Personal translation: "Totalisation of a specific group". 
and motivated aspect of identities, as well as their fragmented and pluralistic processuality. Straub specifies:

Unter einer kollektiven oder Wir-Identität verstehen wir das Bild, das eine Gruppe von sich aufbaut und mit dem sich deren Mitglieder identifizieren. Kollektive Identität ist eine Frage der Identifikation seitens der beteiligten Individuen. Es gibt sie nicht 'an sich', sondern immer nur in dem Maße, wie sich bestimmte Individuen zu ihr bekennen. [...] Nach der nahe gelegten Auffassung sind kollektive Identitäten Konstrukte, die nichts anderes bezeichnen, als eine näher zu spezifizierende Gemeinsamkeit im praktischen Selbst- und Weltverhältnis sowie im Selbst- und Weltverständnis Einzelner ${ }^{23}$ (2004: 299).

Rosa sums it up as follows: Although building blocks of personal identity refer to the collective, "trägt jede Einheitsunterstellung [...] einen potentiell ideologischen und normierenden Charakter. [...] Individuen und Gruppen sind daher stets zu einer dialogischen (und konflikthaften) Klärung kollektiver Identität gezwungen"24 (2007: 51-52).

For the reasons mentioned above we have decided not to choose collective identity as a direct subject of research but to focus instead - more modestly, yet empirically justified - on so-called 'identities' ${ }^{25}$. In doing so, we have investigated the interactions and discrepancies between institutionally 'attributed' and everyday 'appropriated' identities - regardless of whether these were collectively (in whatever constellation) or individually based. This neutral and plural wording aims to emphasise that, in our view, the constructivist and non-essentialistic conceptual approach to the issue of identity is more significant than focussing on the reference units within this field. Moreover, the perspective we have chosen offers fertile ground for the analysis of personal as well as collective 'identity patterns' which we see as reference points on a dynamic spectrum - with its transitions and transgressions. The concept of 'identity pattern' suggests that specific structures of

23 | Personal translation: "By a collective or we-identity, we understand the image which a given group builds of itself and with which its members identify. Collective identity is a question of identification on the part of the individuals involved. It does not exist 'in itself' but only to the extent that specific individuals profess their affiliation. [...] According to this concept, collective identities are constructs that merely denote a shared communality, to be specified in greater detail, in terms of an individual's practical relationship with and image of her/himself and the world around".

24 | Personal translation: "every assumption of unity [...] has a potentially ideological and standardising quality. Hence, [...] both individuals and groups are always forced into a dialogue-based (and conflict-charged) clarification of collective identity".

25 | We are dealing here not with 'national identity', but with 'identities in Luxembourg', not with 'cultural identity' but with the coexistence (in terms of interactions and representations) of everyday identity patterns of people of different origin and different orientations in Luxembourg. 
identities may be revealed empirically; however, there are several of these and they can be shaped with a certain amount of freedom of action in personal effort but in interaction with meaningful others - just the opposite of an innate 'identity' that one 'would carry inside oneself for good' (see Avanza/Laferté 2005; Brubaker 2001). A similar metaphor to the one of 'identity patterns' is that of 'patchwork identity'. It is meant to convey that

[dass von] einzelnen Personen eine hohe Eigenleistung bei diesem Prozess der konstruktiven Selbstverortung zu erbringen ist. Sie müssen Erfahrungsfragmente in einen für sie sinnhaften Zusammenhang bringen. Diese individuelle Verknüpfungsarbeit nennen wir 'Identitätsarbeit', und wir haben ihre Typik mit der Metapher vom 'Patchwork' auszudrücken versucht ${ }^{26}$ (Keupp et al. 2006: 9-10).

We proceed empirically by basing our analysis on the responses of individuals who we either interview personally or by means of a questionnaire, directing our interest on how they design, negotiate and represent their identities, in the sense of a "subjektiver Konstruktionsprozess [...], in dem Individuen eine Passung von innerer und äußerer Welt suchen"27 (Keupp et al. 2006: 7). In actively claiming such identity patterns for themselves, individuals who are geared to the care of the self, find orientation in the midst of a complex role system (see Abels 2006). However, since social circumstances as well as individual thought, action and perception patterns (see Bourdieu 1980) can be synchronically and diachronically subject to change even if not arbitrarily $\mathrm{so}^{28}$ - the resulting identities can, at best, only be "temporary" (Keupp et al. 2006: 276; see Rosa 2007), “transitory”, "processual” (Straub 2004; Straub/Renn 2002), "precarious" or "fundamentally incomplete" (Straub 2004: 280). Self-evaluations and assessments by others too, in identifying various degrees of success or failure, are flexible, historically, socially and culturally alterable, i.e. contingent (see Straus/Höfer 1997). They can be considered as lifelong "projects” or "aspirations", continuously redesigned during interactions - as a snapshot of an

26 | Personal translation: "Individuals are obliged to make a significant personal effort during this process of constructive self-placement. They need to put fragments of experiences into a context that makes sense to them. We call this individual joining work 'identity work', and we have attempted to express its typicality with the 'patchwork' metaphor".

27 | Personal translation: "Subjective process of construction [...] in which individuals seek to harmonise the internal and external worlds".

28 Straub calls this phenomenon, very appropriately, a "structurally anchored mobility" (in 2004: 281). Social conditions and individual aspirations and resources appear to be undergoing change; this change is relative since it still perpetuates social injustice. Whith the overall social structure moving towards liberalisation and culturalisation of everyday life, individuals may subjectively perceive change, yet the socio-cultural milieu affiliations remain much the same (see Vester et al. in 2001) and "predetermine a certain range of possibilities for the development of identities" (Straus/Höfer 1997: 218). 
ongoing process of "technologies of the self" (Foucault 1994; 1984). Even though the identity work is based on "Selbstdistanzierung durch Selbstreflexion und Selbstkritik" 9 (Straub 2004: 282; see Giddens 1991; Bauman 1999), it does not require the subjects' constant attention. For

Subjekte arbeiten (indem sie handeln) permanent an ihrer Identität. Deren Basis(akte) bestehen aus situativen Selbstthematisierungen, die unser Denken und Handeln kontinuierlich begleiten ${ }^{30}$ (Straus/Höfer 1997: 273).

Therefore, the "[individuelle] Antworten auf die (praktische) Identitätsfrage [müssen] nicht unbedingt explizit artikuliert werden"31 (although this is often the case in the narrative and discursive mode); they can also be "dem Handeln [auch] implizit [sein] bzw. handelnd zum Ausdruck gebracht werden"32 (Straub 2004: 280).

However, regardless to what degree this self-reference is reflected, it is a "Sinnfrage"33 (Reckwitz 2001: 22) which in everyday life takes the social and cultural form of a striving for continuity and coherence, "angesichts der Vielfalt lebensweltlicher Selbsterfahrungen und der Abnahme gesellschaftlich verfasster Kohärenzmodelle"34 (Straus/Höfer 1997: 270).

This claim need not necessarily be free of contradiction; it is rather a matter of finding a meaningful balance between synchronous coherence and flexibility on the one hand and diachronous continuity and change on the other (Rosa 2007: 48). The dynamism of this "stimmig[e] aber kontingent [e]"35 (Straub 2004: 287) structure corresponds more to the concept of selfhood (or ipseity, from Latin ipse, self), than to that of equality (or identity, from Latin idem, equal, identical). Ricoeur (1990) makes reference to this dual meaning of the concept of identity, idem and ipse, in order to point out that the latter dimension puts more emphasis on change and subjectivity while implying the link to alterity.

We subscribe to this approach to identity and identities on the basis of ipseity, because we feel it clearly indicates our wish to avoid the latent danger inherent to contemporary identity theories as outlined by Reckwitz. He distinguishes between 'classical' concepts (1940s to 1970s) - which were "universalistisch und

29 | Personal translation: "Self-dissociation through self-reflection and self-criticism".

30 | Personal translation: "By acting, subjects are permanently at work on their identities Their basic acts comprise situative self-thematisations that continuously accompany our thoughts and activities" (Straus/Höfer 1997: 273).

31 | Personal translation: "[Individual] answers to the (practical) question of identity [...] need not necessarily be articulated explicitly"

32 | Personal translation: "Implicitly implied in the action or expressed through action".

33 | Personal translation: "Question of meaning".

34 | Personal translation: "In view of the diversity of experiences of self-awareness in everyday life and a progressive paucity of coherence models provided by society".

35 | Personal translation: "Consistent but contingent". 
kompetenztheoretisch orientiert und auf das Problem des Verhältnisses zwischen Individuum und sozialen Zwängen sowie das Problem der temporalen Konstanz zentriert" 36 - and models from the 1970 s onwards, which were rather "hermeneutisch und historisch orientiert sowie auf das Problem des kontingenten Selbstverstehens bezogen"37 (2001: 25). According to Reckwitz, these current theories run a dual risk of overinterpretation: on the one hand, due to the "Dramatisierung der Stabilität von Differenzen" ${ }^{8}$, which suggests a certain culturalistic essentialism; on the other hand, due to the "Dramatisierung der permanenten Veränderbarkeit von Identitäten"39, i.e. the "Bild eines hyperflexiblen, seine Identitäten austauschenden Subjekts [...], das den Boden der Alltagspraktiken zu verlassen scheint"40 (2001: 34-35). The reference to ipseity serves as a reminder that the identities we have investigated carry the respective differences inherently as a complement (see Rosa 2007) and that they have been empirically ascertained in terms of their social embeddedness and milieu affiliation.

To sum up, we have, in order to stress the relational nature of identity patterns, directed our attention to the intricate interplay between the different forms of internal self-understanding and self-relationship and external influences, or, in other words, on the interplay between bottom up "identifications with" and top down "identifications of" (Hark 1999). The circulating identity projects and options - analysed here in the form of representations and negotiations - are intrinsically dialogical and political. There is a negotiation of "Machtkämpfe um die Bedeutung, Stellung und den Wert von Lebensformen, Eigenschaften, Tätigkeiten und Verhaltensweisen" ${ }^{11}$ (Rosa 2007: 52). Identities are formed for the most part in linguistic and everyday-cultural negotiations as well as in spatial representations and in the confrontation between images of self and others, which is why these thematic areas are empirically elaborated in this book and interlinked with the cross-cutting theme of socio-cultural milieus (Vester et al. 2001). Our primary focus of interest here are the active processes currently in progress, involving the different forms of identity work of the conscious self - in other words Doing Identity.

36 | Personal translation: "Which had a universalistic and competence-theoretical orientation and centred on the problem of the relationship between the individual and social constraints as well as on the problem of temporal constancy".

37 | Personal translation: "Hermeneutically and historically oriented as well as relating to the problem of contingent self-understanding".

38 | Personal translation: "Dramatisation of the stability of differences".

39 | Personal translation. "Dramatisation of the permanent changeability of identities".

40 | Personal translation: "Image of a hyper-flexible subject permanently changing its identities [...], which seems to depart from everyday practices".

41 | Personal translation: "Power struggles over the meaning, status and value of lifestyles, characteristics, activities and behaviours". 


\section{Analytical Categories and Research Design}

In order to apply it in our interdisciplinary project, we have operationalised the identity concept as defined within the general theoretical framework presented above. For this, we have adopted two different perspectives that are only separable for analytical purposes and that give rise to a third perspective, which seems crucial for statements about current and possibly also future social developments. This involves, on the one hand, the concept of attributed and appropriated identities and on the other, their interdependency. With the aid of the concept of attributed identities, the attributions and structural mechanisms of the so-called 'desirable identities' are examined as to how they manifest themselves in the discourses in politics and the media. This means that the research interest here focuses on identity-related attribution processes via vectors in different areas of society. By contrast, the concept of appropriated identities refers to the identity patterns articulated in social practice. Of particular interest here are the so-called 'lived identities' of the Luxembourg resident population in different socio-cultural milieus which - according to our initial thesis - relate transversely to milieu-specific dispositions. Finally, by making a contrastive comparison of attributed and appropriated identities according to the respective thematic fields under investigation, it is possible to indicate the interplay and possibly also the divergences between both analytical categories, which should be seen as an approach to social practice in terms of a structure-agency link (see Giddens 1997) in the field of identity construction.

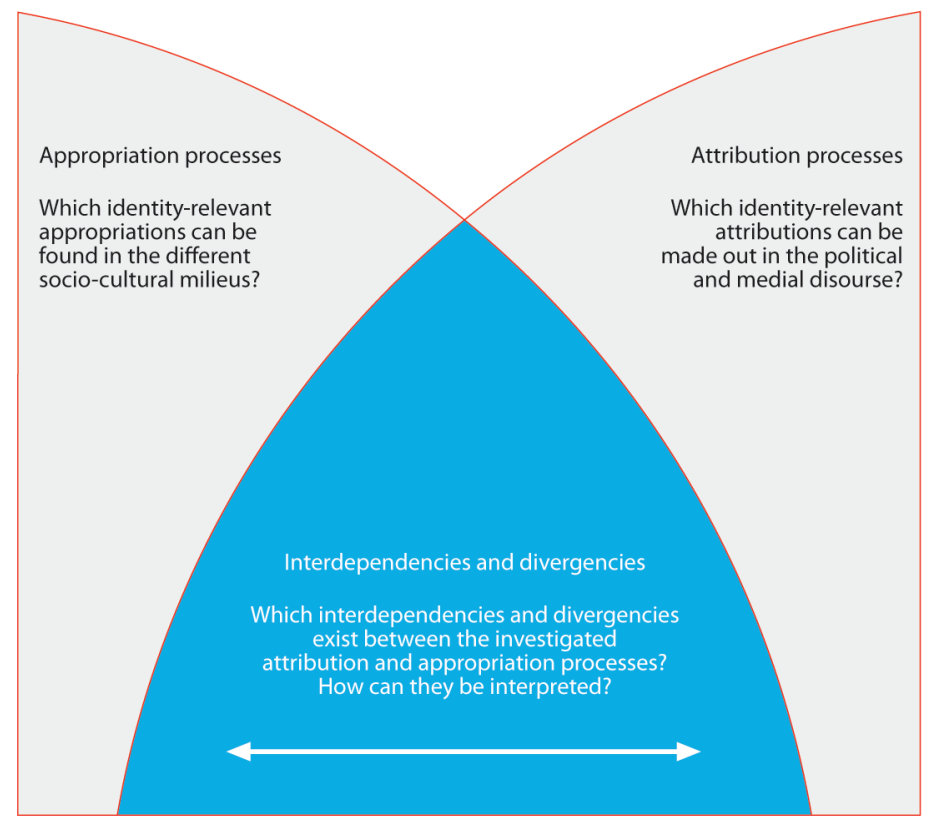

Figure 1: Heuristics of processes of identity construction. 
On the basis of the analytical foundation of the identity concept and against the background of the disciplines represented in the IPSE research unit, five main thematic areas have emerged that have structured the project.

- Socio-cultural Milieus in Luxembourg (chap.3): For a differentiated and transversal examination of appropriated identities, we first of all empirically identified socio-cultural milieus in Luxembourg society. The category of milieus describes people with their typical attitudes and life orientations and incorporates these into social groups with accordingly similar value orientations, life goals and lifestyles. The pioneering work of identifying milieus follows the social milieu approach proposed by Pierre Bourdieu, further developed by Michael Vester (see Vester et al. 2001) and adapted in the framework of the IDENT project, taking into account the plural conditions in Luxembourg. The identified socio-cultural milieus - and the appropriated identities reflected in them - are an integrating element of the IDENT project, as becomes clear by the continuous reference to milieu classification by the authors of the thematic areas below.

- Languages and Identities (chap. 4): Another thematic area centres on linguistic identities in multilingual Luxembourg. We have first looked at aspects of contact between languages as well as the experience of multilingualism, which differentiated in terms of sociocultural milieus - provides insights into languagerelated identities. Appropriated identities are also examined in connection with the question of which conflict lines and positions characterise the social debate surrounding multilingualism. Finally, we have investigated in which way 'lived' or 'desired' linguistic identities are articulated in the public space.

- Spaces and Identities (chap. 5): This focus area is concerned with spatial identities, the central point of interest here being the attributed identities and their representations in the tourism discourse. Observations extracted from communication media ranging from the local to the inter-regional level are contrasted with the notions of space and spatial practices of Luxembourg residents, whereby we were able to elucidate the discrepancies between attributed and appropriated identities on different levels of scale.

- Images and Identities (chap. 6): This thematic area involves linguistically and visually created images of self and others in regard to 'Luxembourg', as found in specialised and popular media. It explores the question which conclusions can be drawn from the statements made as well as from the genesis of the viewed images, in respect to identity-related appropriation and attribution processes. The work carried out in this area of our project places particular emphasis on the analytical nature of the conceptual categories which (may) converge in the process of reception of the investigated media.

- Everyday Cultures and Identities (chap. 7): This thematic area focuses on appropriated and attributed identities in the everyday - yet politically and economically moulded - contexts of gender, consumerism and alterity. Of special interest here are the identities observed in various socio-cultural milieus 
in regard to their ambivalent appropriation in the practice of everyday culture, where 'resolved contradictions' but also overlaps emerge.

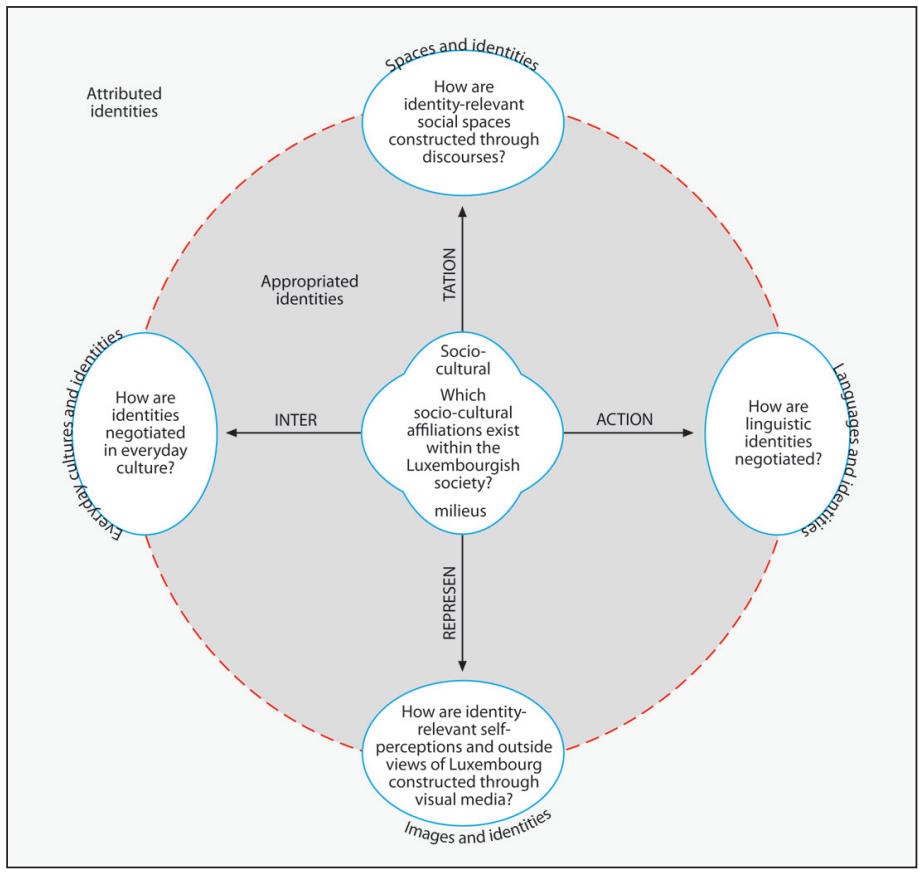

Figure 2: Thematic areas and their conceptual framework.

Defining the position the project occupies within the scientific discussion about identity and identities and the elaboration of analytical categories has, during the three years of research, proven indispensable for establishing a common basis for interdisciplinary collaboration. In the following paragraphs, we will explain the methods used in analysing the subjects of investigation in the thematic areas described above and subsequently present some points relating to research practice in terms of our scientific interdisciplinary collaboration.

\subsection{Methodology and Interdisciplinary Collaboration}

Based on the thematic-conceptual framework outlined above, we will, in the following, explain the methods employed and provide insights into the structure and implementation of the project stages that were jointly worked on, in particular those of the empirical survey. To begin with, we wish to give an overview of the topics examined in the thematic areas. 
- Socio-cultural milieus: The identification of socio-cultural milieus within Luxembourg's residential population for the examination of appropriated identities was based on the analysis of quantitative statistical data that were gathered within the framework of the IDENT project.

- Languages and Identities: For the investigation of identities regarding contact between and experience with languages, we first used quantitative statistical data from the present study; in addition, we evaluated by means of textanalytical methods letters to editors in the relevant print media of Luxembourg as to the positions represented in them. Finally, public signs in Luxembourg were subjected to a quantitative analysis to reveal appropriated and attributed linguistic identities.

- Images and Identities: Images of self and others as attribution or appropriation of identities were identified in both popular and specialised media such as newspapers, comics, exhibition catalogues, print advertisements or photographs and subsequently discussed. Here we applied for the most part content-analytical procedures which were supplemented by quantitative statistical data from the present study.

- Spaces and Identities: In this thematic area, the attribution of spatial identities was deconstructed in a discourse-analytical approach using tourist pamphlets, topographic maps, travel guides and journalistic publications. They were contrasted with appropriated spatial identities of Luxembourg's resident population, which were identified on the basis of the data of our own quantitative and qualitative survey.

- Everyday Cultures and Identities: The identities of everyday practice involving the appropriation or attribution of gender constructions, views concerning 'good' food and experiences with cross-border workers are based on the data of our own quantitative and qualitative surveys and on corresponding content analyses in which we also evaluated official pamphlets and legal texts.

The presentation of the topics investigated in the individual thematic areas indicates a broad range of 'subjects of analysis'. This diversity was managed by employing similarly varied methodological instruments and an approach based on the division of labour, which has become possible only thanks to the experience and the broad methodological competence of the disciplines represented in the IPSE research unit. The applied methodological procedures can be summarised under the project modules "quantitative survey", "qualitative interviews" and "content analyses".

\section{Quantitative Survey}

A crucial part of the IDENT project was the quantitative representative survey of Luxembourg's resident population. It aimed to achieve two goals: On the one hand, to identify socio-cultural milieus of Luxembourg society and the identity patterns to be found there; on the other, to elaborate specific questions from the thematic 
areas (languages, images of self and others, spaces and everyday cultures) under the aspect of identity construction. Accordingly, the questionnaire jointly developed by us is subdivided into different thematic areas ${ }^{42}$, which were operationalised by using open, half-open and closed questions. The multilingualism in the Grand Duchy of Luxembourg made it necessary to create a Luxembourgish, German, French, English and Portuguese version of the questionnaire (just like the interview guideline presented below). However, the survey results could only be put into relation to each other if it was guaranteed, by means of the interview tools, that the treated topics and/or key concepts retained the same meaning - what is referred to in the methodological debate as "functional equivalence" (see Braun 2006). This touches on the multi-layered and socio-culturally anchored range of meaning of lexical elements, which raises the question, when it comes to the translation of interviewing tools, as to what extent, or whether at all, the target language can provide equivalent wording that excludes semantic shifts ${ }^{43}$. This involves both the level of denotation, as in the case of educational qualifications, and that of the connotation, when using, for example, socially charged concepts (see Lüsebrink 2005: 47). One way of conducting an equivalence check is to create a backtranslation, entailing the transfer of a questionnaire or interview guideline from the target language back into the source language by unbiased translators, in order to then be able to exclude semantic shifts by comparing the resulting text with the source version of the respective interviewing tool. In addition, there are discursive procedures, where the translations of interviewing tools are discussed with persons sensitised to functional equivalence or with native speakers. Since we had persons with these qualifications at our disposal, as well as bilingual and sometimes even trilingual native speakers, we chose for the IDENT project the discursive procedure of equivalence check, which was applied in several joint and structured sessions.

The composition of the random sample was carried out by the leading polling institute in Luxembourg, which was also responsible for conducting the quantitative survey. Between October 2008 and February 2009 a total of 1,579 people of age 16 and above as well as resident in the Grand Duchy of Luxembourg were interviewed. Two thirds of the interviews were conducted via Internet (computer-assisted web interview), the remaining third by telephone (computer-assisted telephone interview), in order to be able to reach both persons with media competence and those with more traditional media usage. The random sample was weighted according to the variables of age, gender, region, nationality and employment (status) and is

42 | See section 3.2 for a detailed treatment.

43 | One should mention that due to subjective reception mechanisms even in a monolingual investigation context the interviewees rarely reconstruct meanings in absolutely identical ways. 
representative for the inhabitants of Luxembourg. The gathered data were evaluated via the processes of descriptive and multivariate ${ }^{44}$ statistics $^{45}$.

\section{Qualitative Interviews}

On the basis of the quantitative representative survey outlined above, additional interviews were conducted in spring 2009 with those residents of Luxembourg who had agreed to this in the quantitative survey. The decision to carry out a largescale qualitative survey was motivated by the desire to be able to make statements on subjective attributions and interpretations of meaning that a quantitative procedure would have been unable to capture. Consequently, the project partners decided to jointly conduct focussed interviews. This is an open to partlystandardised procedure which is supported by an interview guideline and aims for in-depth re-presentation (Repräsentan $z^{4}$, see below) instead of representativity (Repräsentativität) (Lamnek 2005).

Due to the significant academic interest attached to the interview survey, we developed three thematic interview guidelines ("everyday cultures", "images of self and others", "languages and spaces") in which concisely worded questions and conversation-generating impulses were noted down. The thematic teams, which had developed the individual questions, were asked to state in point form the background or the aim of the respective question. This approach enabled the interviewers - who had become familiar with the questions in the course of their joint work on the project, but had not necessarily internalised the strategic thrust of all of them - to prepare individually for the interviews, which were shared out among the members of our research team. Hence, the detailed interview guidelines were edited down to point form by the researchers, which in turn allowed for a flexible and in most part open interview procedure. Two meetings were organised to promote the dialogue between the authors of the questions and the interviewers, who were not necessarily identical.

It was not the aim of the interview survey to determine specific frequencies of phenomena, but rather to arrive at a detailed understanding of social phenomena, i.e. to examine the nature of their in-depth representation (Repräsentanz). In other

44 See section 3.2 for a detailed presentation.

45 | The complete data collection including the questionnaire can be inspected at the Luxembourg University library.

46 | The contrast between Repräsentanz and Repräsentativität is not easily translatable into English from its German sociological origin: Repräsentanz signifies the specifically qualitative form of scientific insight, i.e. the multi-facetted "representing something", "being vivid, eloquent, meaningful", that is to say, an in-depth understanding of selected case examples, with the aim to embrace the widest possible spectrum of meanings of a given phenomenon. It is opposed to quantitative methods that give priority to a larger, comparable, abstracting yet more superficial representativity (Repräsentativität). 
words, our interest was not so much focussed on a random sample in order to be able to form conclusions about a general population, as on examining concrete and varied cases in order to record a phenomenon in the most multi-faceted manner possible. When it came to sampling, this approach required "[...] eine Entscheidung gegen den Zufall und eine theoretisch-systematische Auswahl [der zu Befragenden]"47 (Lamnek 2005: 186). Lamnek is here referring to the deliberate procedures of qualitative random sample implementation, which include, among others, the advance specification of the sample structure (Weischer 2007: 207-209). Central criteria of the deliberate random sample configuration were gender, age and nationality, designed to illustrate the plurality of the Luxembourg population. This has been achieved to a large extent with the interview random sample that comprised 75 people.

\begin{tabular}{|c|c|c|c|c|c|c|}
\hline & $\begin{array}{l}\text { Topic: } \\
\text { Every Day } \\
\text { Cultures } \\
\end{array}$ & $\begin{array}{l}\text { Topic: Images } \\
\text { of Self and } \\
\text { Others }\end{array}$ & $\begin{array}{l}\text { Topic: } \\
\text { Languages } \\
\text { and Spaces }\end{array}$ & Total & $\begin{array}{l}\text { Luxembourg } \\
\text { Population } \\
(2007)^{*}\end{array}$ & $\begin{array}{l}\text { Deviation } \\
\text { from Parent } \\
\text { Population }\end{array}$ \\
\hline \multirow[t]{2}{*}{$\begin{array}{l}\text { Random } \\
\text { sample (N) }\end{array}$} & $\mathrm{n}=27$ & $n=26$ & $\mathrm{n}=22$ & $\mathrm{~N}=75$ & 476,200 & Percentage \\
\hline & (a) & (b) & (c) & (d) & (e) & (d-e) \\
\hline \multicolumn{7}{|l|}{ Gender } \\
\hline Men & 50.0 & 48.1 & 40.9 & 46.7 & $49 \cdot 5$ & -2.8 \\
\hline Women & 50.0 & 51.9 & 59.1 & $53 \cdot 3$ & 50.5 & 2.8 \\
\hline \multicolumn{7}{|l|}{ Age group } \\
\hline $15-29$ & 23.1 & 11.1 & 13.6 & 16.0 & 22.6 & -6.6 \\
\hline $30-44$ & 30.8 & $44 \cdot 4$ & 27.3 & 34.7 & 29.8 & $4 \cdot 9$ \\
\hline $45-59$ & 26.9 & $25 \cdot 9$ & 31.8 & 28.0 & $24 \cdot 7$ & $3 \cdot 3$ \\
\hline $60+$ & 19.2 & 18.5 & 27.3 & 21.3 & 22.8 & -1.5 \\
\hline \multicolumn{7}{|l|}{ Nationality } \\
\hline Luxembourgers & 61.5 & 55.6 & 63.6 & 60.0 & 59 & 1.0 \\
\hline $\begin{array}{l}\text { Resident } \\
\text { foreigners }\end{array}$ & 38.5 & $44 \cdot 4$ & 36.4 & 40.0 & 41 & -1.0 \\
\hline \multicolumn{7}{|l|}{ Of these } \\
\hline French & 10.0 & 8.3 & 12.5 & 10.0 & 12.7 & -2.7 \\
\hline Portuguese & 40.0 & $33 \cdot 3$ & 25.0 & $33 \cdot 3$ & 37 & -3.7 \\
\hline Germans & 10.0 & 8.3 & 0.0 & 6.7 & 5.7 & 1.0 \\
\hline Belgians & 10.0 & 8.3 & 12.5 & 10.0 & 8.3 & 1.7 \\
\hline Italians & 10.0 & 8.3 & 12.5 & 10.0 & 9.6 & 0.4 \\
\hline British/Dutch & 0.0 & 8.3 & 0.0 & $3 \cdot 3$ & $4 \cdot 4$ & -1.1 \\
\hline Other & 20.0 & 25.0 & 37.5 & 26.7 & 8.3 & 18.4 \\
\hline
\end{tabular}

Table 1: Random samples of the qualitative surveys by socio-demographical characteristics (Source: Own study; * Statec 2007).

47 | Personal translation: "[...] A decision against chance and a theoretical-systematic selection [of the persons to be interviewed]". 
The interviews were conducted by the members of the research team, according to language preferences, time availability and thematic interest, so that each participant in the project had around five people to interview. A central objective was the interdisciplinary distribution of the interviewers who therefore worked with guidelines that had been developed by another thematic team. The interviews took place by prior arrangement in the homes of the interviewees, in their familiar surroundings and often in the early or late hours of the day. The conversation that lasted between one and one and a half hours, was directed, following the interview guideline, towards a specific topic with its various aspects and the interviewees were given the possibility to express themselves freely, however within certain thematic boundaries. In this way, it was possible to obtain the interviewees' interpretations and reactions in a relatively open manner and make room for aspects not anticipated by the researchers. The digitally recorded interview data were processed using transcription into standard language (Mayring 2007: 91), since the focus of the interviews was on thematic content. This approach, which involves, among other things, the minimal correction of errors in syntax and editing the flow of words, aims at enhancing the readability of the spoken language. The task of transcribing the interviews in Luxembourgish, German, French, English and Portuguese was entrusted to student assistants.

The final interview transcripts were then evaluated by computer, using deductive-selective encoding and/or inductive-free encoding. As a first step, the transcripts were systematised by the project participants following a jointly adopted codification pattern with predefined codes and subcodes (coarse coding). This pattern was elaborated during several joint "codification meetings", during which the direct exchange between the project participants was both possible and essential. During the subsequent inductive-free encoding, performed by those colleagues specialised in the respective thematic fields, aspects were brought into focus that had hitherto not been taken into account but had come up during the interview, by using key quotes and memo functions inherent to the software (fine coding); situative descriptions of the interaction, written down by the interviewers after every conversation, were also added by memo function. This made it possible to further differentiate the code structure in terms of the so-called fine coding. The texts prepared in this way were evaluated by synoptic analysis (Kelle 2007: 491-493), which in respect to methodology is part of the phenomenological analysis developed by Mayring (Mayring 2002: 107-108) and in technical respect one of the simple retrieval techniques. Its aim is to identify and clarify differences, similarities and relationships between the subjective structures of meaning, through the variation or the process of comparison, as described by Glaser and Strauss (Glaser/Strauss 2005: 107-122) already in the 1970s, in order to penetrate to the "[den] Wesenskern der Phänomene" 48 (Mayring 2002: 108). For this purpose, text segments of one or several codes were compiled in a list (text retrieval), which then permitted us to 
compare and interpret differences and similarities. To ensure a smooth handling of the described procedure of computer-assisted analysis of qualitative data, we organised a number of training sessions and internal workshops, which were conducted both by the project participants and by invited experts.

In addition to the large-scale qualitative survey, experts from specific areas of society were interviewed by some of our researchers. In these qualitative expert interviews, however, it was not so much the experts that were the subject of analysis, that is to say not "[...] die Person mit ihren Orientierungen und Einstellungen im Kontext des individuellen oder kollektiven Lebenszusammenhangs"49 (Meuser/Nagel 2005: 72-74). Rather, the experts' function here was to inform about institutional or organizational contexts (Weischer 2007: 281). The goal of the interviews was therefore to identify specific stocks of knowledge the experts in question had acquired in their professional field and that provided insights into concrete areas of investigation. An expert was considered anyone who carries responsibility for specific forms of problem solution in a given field of investigation or who has privileged access to information about social actors. The expert interviews were prepared, conducted and evaluated by those project participants whose particular research interest connected with the interviewees' fields of expertise. They included the areas of administration, culture and economics.

\section{Content Analyses}

Apart from the quantitative and qualitative surveys outlined above, we also applied, in view of the considerable variety of investigated items, methods that can be summarised under the concept of content analysis. These involve, based on a broad approach to the text, text-analytical procedures comprising discourse-analytical methods and semiotic techniques. The methods used will be explained more fully in the respective sections.

As indicated earlier, investigating the various thematic areas necessitated a variety of methodical procedures leading to an abundance of empirical data. The project participants representing the different disciplines judiciously intertwined the available qualitative and quantitative data according to thematic orientations. On the one hand, in combining quantitative and qualitative methods and corresponding data, we wanted to ensure the validity of the investigation results, and on the other, it was our goal to supplement the perspectives on the subjects of investigation, by bringing together the different aspects of a phenomenon to form a complete and composite picture (Kelle/Erzberger 2007: 302-304). We were able to implement this procedure, referred to as "triangulation" (see Denzin/Lincoln 2005) in the methodological debate, in numerous team meetings and internal workshops.

49 | Personal translation: “[...] The person with her/his orientations and attitudes in the context of individual or collective everyday life contexts". 


\section{Interdisciplinary Collaboration}

The contributions in this book are not a compilation of single research projects, but the result of a three-year long, intensive collaboration between scientists from various disciplines. In the following, we would like to present a brief overview of what this interdisciplinary collaboration entails and how the IDENT project is organised. It was carried out between 2007 and 2010 under the direction of Christian Schulz, who was closely supported by a steering committee consisting of other project members. In addition to this strategical level, an IDENT coordination office was established in which Rachel Reckinger and Christian Wille coordinated the operative tasks and prepared strategic decisions. The research work was carried out by the IDENT project group, which included representatives from the fields of English Studies, Gender Studies, Geography and Spatial Planning, German Studies, History, Intercultural Communication, Luxembourgish Studies, Media Sciences, French Studies, Sociology and Visual Arts. The level of the operative tasks, that is to say the organisational forms and the implementation of the research projects which will be considered in greater detail below. They can be subdivided into three core stages: Preparatory stage (2007-2008), empirical stage (2008-2009) and final stage (2009-2010).

In the course of the project, a variety of collective working methods of interdisciplinary collaboration were used, which include thematic teams, internal workshops, round-table discussions and international conferences.

Thematic teams: In order to enable an intensive exchange between the project partners, we formed different thematic teams, one set with a permanent and thematic orientation, and another set with a temporary and methodological one. The thematic teams maintained over the entire duration of the project each focussed on one of the thematic areas outlined above. The thematic teams, which convened every two to three weeks, depending on the particular phase of the project, were staffed with five or six researchers from the following disciplines:

\begin{tabular}{|c|c|c|c|c|}
\hline $\begin{array}{l}\text { TT Socio-cul- } \\
\text { tural milieus }\end{array}$ & TT Languages & $\begin{array}{l}\text { TT Images of } \\
\text { Self and Others }\end{array}$ & TT Spaces & $\begin{array}{l}\text { TT Everyday } \\
\text { Cultures }\end{array}$ \\
\hline $\begin{array}{l}\text { Sociology, Ger- } \\
\text { man Studies }\end{array}$ & $\begin{array}{l}\text { German } \\
\text { Studies, Lux- } \\
\text { embourgish } \\
\text { Studies }\end{array}$ & $\begin{array}{l}\text { Visual Arts, } \\
\text { German Stud- } \\
\text { ies, History, } \\
\text { Media Sciences }\end{array}$ & $\begin{array}{l}\text { French Stud- } \\
\text { ies, History, } \\
\text { Geography and } \\
\text { Spatial Plan- } \\
\text { ning }\end{array}$ & $\begin{array}{l}\text { Gender Stud- } \\
\text { ies, English } \\
\text { Studies, Sociol- } \\
\text { ogy, Intercul- } \\
\text { tural Commu- } \\
\text { nication }\end{array}$ \\
\hline
\end{tabular}

Table 2: Thematic teams. 


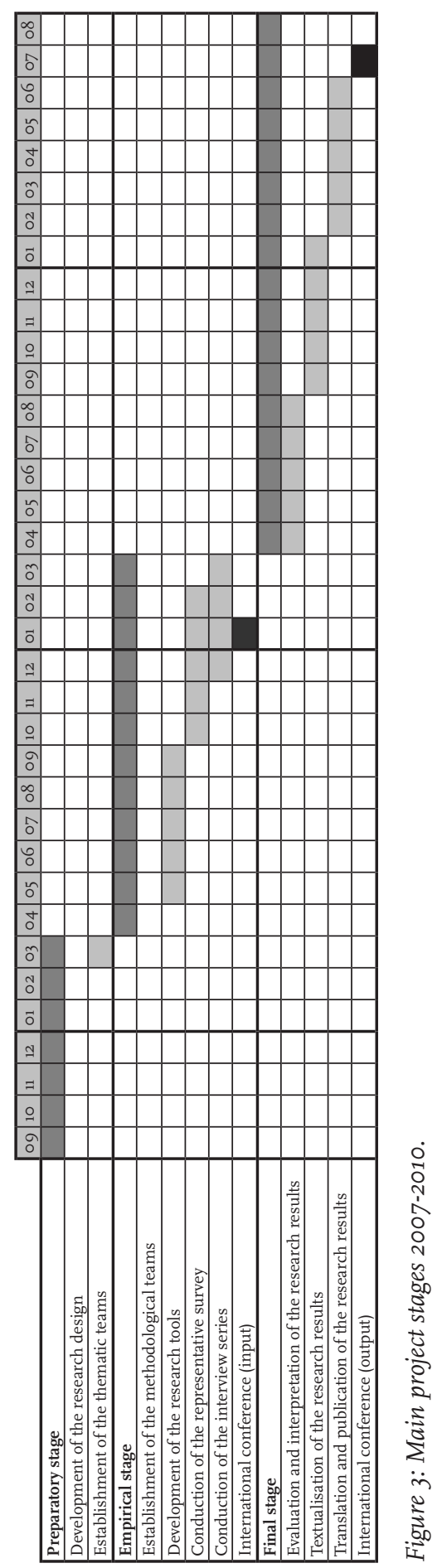


The tasks of the thematic teams consisted, depending on the project stage, in developing a common theoretical-conceptual framework and research design, gathering and processing empirical data, jointly interpreting the research results and writing a chapter for this book. The research within the thematic teams was conducted around different case examples, which were elaborated and discussed in the perspective of a common research question. The thematic teams were assisted and supervised in their activities by the project coordinators, one of the challenges being to synchronise these five thematic teams, each with its specific features, in a conceptual and methodological way, according to the requirements of the main project stages.

Other teams, formed only during certain stages of the project, had a methodological mandate. It was their task to develop the multilingual research instruments in close collaboration with the thematic teams. Accordingly, the multidisciplinary methodological teams "Questionnaire" and "Interview" collected and integrated the questions compiled by the thematic teams, checking the wording and processing them for the quantitative and qualitative research instruments. They were also responsible for the pretests, which, for the "Interview" team, included organising two trainings on interview techniques using role plays, as well as one training on computer-aided interview processing for interpretative work.

Internal workshops: In order to avoid a fragmentation of the IDENT project group as a result of scientists working in different thematic teams, we also organised a series of internal project workshops. All project participants assembled every four to eight weeks in plenary sessions where different issues were discussed, depending on the particular project stage. While in the project preparation stage, the workshops mainly served to share information about the various disciplines' specific features and to reach, to some degree, a common and cross-disciplinary understanding of certain concepts, the internal workshops were also indispensable for jointly working out the project architecture. Particularly during the empirical stage, the plenary sessions were an important instrument for communicating about organisational problems of complex survey procedures. The internal workshops conducted by the project coordinators were used particularly towards the end of the project to share and link information on the results presented by the thematic teams. Due to the limited time available in the workshops, we organised an additional 2-day symposium to allow sufficient room for interpreting the research results in a comprehensive exchange of information, embracing all thematic teams and disciplines involved in the project.

Round-table discussions: In addition to the regular workshops, we set up a series of round-table discussions designed to give participants the opportunity to meet with external experts in a relaxed atmosphere. In particular during the stage of project preparation, consultation with experts, who had already worked on similar problems, proved very helpful for the development of the common theoreticalconceptual framework, the project architecture and the research instruments that were finally used. We would especially like to thank the following for their 
support: Michael Vester and Daniel Gardemin (Hannover University), Jean-Marie Klinkenberg (University of Liège) and Jürgen Pohl (Bonn University).

International conferences: The international conferences organised in the course of the project provided a further platform for sharing information with experienced scientists in the area of identity research. These events were strategically integrated into the project, so that we can distinguish between an 'input conference' (2009) and an 'output conference' (2010). The conference organised in 2009, with the title "IDENT - Socio-Cultural Identities: Interaction and Representation", invited selected lecturers to give their critical appraisal of the approach and the concept of the IDENT project, besides providing an overview of their own work. For the resulting suggestions which were subsequently incorporated into the project, we would like to extend our sincere thanks to Brigitta Busch (Vienna University), Thomas Dörfler (University of Bayreuth), Britta Kalscheuer (University of Frankfurt/M.), Claudia Lenz (Center for Studies of Holocaust and Religious Minorities, Oslo), Albert Lévy (Université Paris VIII), Lydia Martens (Keele University), Rolf Parr (Bielefeld University), Albert Raasch (University of the Saarland), Klaus Sachs-Hombach (University of Applied Sciences, Chemnitz) and Jürgen Straub (Ruhr-University Bochum). The 2010 conference with the title "Doing Identity in Luxembourg: Subjective Appropriations - Institutional Attributions - Socio-Cultural Milieus" had been organised to present the research results both to a professional audience and the interested public and to invite critical discussion.

Besides these forms of interdisciplinary collaboration, we, as coordinators of the project, would like to mention some experiences that were made in the course of the project. One of them is that in other projects of similar scale, sufficient room should be given to those processes that promote exchange and convergence between different disciplines. This means showing patience and also allowing for a certain amount of confusion and 'talking at cross purposes'; intervening with empathy in communication processes and negotiating or 'translating' these in a results-oriented manner. Frequently, it is only the use of different words that stops people from realising that they are talking about the same thing. What really helps here is to take a broad, analytical look at professional contents and engage with the researchers with understanding and empathy for their particular personality. At the University of Luxembourg, with a staff that comes from various European countries as well as from overseas, it takes an additional effort to integrate the diversity of languages and the different experiences of university socialisation into day-to-day academic life. This requires intercultural skills as well as disposable time, which ultimately, however, serves to enrich and enhance the experience of interdisciplinary teamwork. 


\subsection{RefERENCES}

Abels, Heinz. 2006. Identität. Über die Entstehung des Gedankens, dass der Mensch ein Individuum ist, den nicht leicht $\mathrm{zu}$ verwirklichenden Anspruch auf Individualität und die Tatsache, dass Identität in Zeiten der Individualisierung von der Hand in den Mund lebt. Wiesbaden: VS Verlag für Sozialwissenschaften.

Ahbe, Thomas. 1997. Ressourcen - Transformationen - Identität. In Identitätsarbeit heute. Klasssische und aktuelle Perspektiven der Identitätsforschung, ed. Heiner Keupp/Renate Höfer, 207-26. Frankfurt/M.: Suhrkamp.

Appadurai, Arjun. 1998. Globale ethnische Räume. In Perspektiven der Weltgesellschaft, ed. Ulrich Beck, 11-40. Frankfurt/M.: Suhrkamp.

Avanza, Martina and Gilles Laferté. 2005. Dépasser la 'construction des identités'? Identification, image sociale, appartenance. Genèses. Sciences sociales et histoire, no. 61: 134-52.

Baltes-Löhr, Christel. 2006. Migration und Identität. Portugiesische Frauen in Luxemburg. Frankfurt/M. \& London: IKO-Verlag für Interkulturelle Kommunikation.

Bayart, Jean-François. 1996. L'illusion identitaire. Paris: Fayard.

Bhaba, Homi. 1994. The location of culture. London: Routledge.

Bauman, Zygmut. 1999. Unbehagen in der Postmoderne. Hamburg: Hamburger Edition.

Bourdieu, Pierre. 1992. Die verborgenen Mechanismen der Macht. Hamburg: Vsa.

Bourdieu, Pierre. 1980. Le sens pratique. Paris: Editions de Minuit.

Bourdieu, Pierre. 1972. Esquisse d'une théorie de la pratique. Précédé de trois études d'ethnologie kabyle. Paris: Le Seuil.

Braun, Michael. 2006. Funktionale Äquivalenz in interkulturell vergleichenden Umfragen: Mythos und Realität. Mannheim: ZUMA.

Brubaker, Rogers. 2001. Au-delà de l'identité'. Actes de la recherche en sciences sociales, no. 139: 66-85.

Chilla, Tobias. 2009. Europa in Luxemburg: Die EU-Institutionen. In Der Luxemburg Atlas du Luxembourg, ed. Patrick Bousch, Tobias Chilla, Philippe Gerber et al., 16-17. Köln: Emons.

Denzin, Norman K. and Yvonna S. Lincoln, ed. 2005. The SAGE handbook of qualitative research. London: SAGE.

Eickelpasch, Rolf and Claudia Rademacher. 2004. Identität. Bielfeld: Transcript.

Elias, Norbert. 1986. Figuration. In Grundbegriffe der Soziologie, ed. Bernhard Schäfer, 88-91. Opladen: Leske + Budrich.

Fehlen, Fernand and Isabelle Pigeron-Piroth. 2009. Mondialisation du travail et pluralité des marchés du travail: L'exemple du Luxembourg. Transcript of the discussion contribution for 12è Journées de Sociologie du Travail, 25 et 26 juin 2009, GREE, Université de Nancy. 
Foucault, Michel. 1994. Technologies of the self. In The essential Foucault. Selections from the Essential Works of Foucault 1954-1984, ed. Paul Rabinow and Nicolas Rose, 145-69. New York \& London: The New Press.

Foucault, Michel. 1984. Histoire de la sexualité. Tome 3: Le souci de soi. Paris: Gallimard.

Giddens, Anthony. 1997. Die Konstitution der Gesellschaft. Frankfurt/M./New York: Campus.

Giddens, Anthony. 1991. Modernity and Self-Identity. Cambridge: Polity.

Giesen, Bernhard. 1999. Identität und Versachlichung. Unterschiedliche Theorieperspektiven auf kollektive Identität. In Identität und Moderne, ed. Herbert Willems and Alois Hahn, 389-403. Frankfurt/M.: Suhrkamp.

Glaser, Barney G. and Anselm L. Strauss. 2005. Grounded Theory. Strategien qualitativer Forschung. Bern: Huber.

Goffman, Erving. 2003. Wir alle spielen Theater. Munich: Piper.

Greverus, Ina-Maria. 1995. Die Anderen und Ich. Darmstadt: Wissenschaftliche Buchgesellschaft.

Halpern, Catherine. 2009. Identité(s). L'individu, le groupe, la société. Paris: Editions Sciences Humaines.

Hark, Sabine. 1999. Deviante Subjekte. Die paradoxe Politik der Identität. Opladen: Leske + Budrich.

Kaufmann, Jean-Claude. 2004. L'invention de soi. Une théorie de l'identité. Paris: Armand Colin.

Kelle, Udo. 2007. Computergestützte Analyse qualitativer Daten. In Qualitative Forschung. Ein Handbuch, ed. Uwe Flick, Ernst von Kardoff and Ines Steinke, 486-502. Hamburg: Rowohlt.

Kelle, Udo and Christian Erzberger. 2007: Qualitative und quantitative Methoden: kein Gegensatz. In Qualitative Forschung. Ein Handbuch, ed. Uwe Flick, Ernst von Kardoff and Ines Steinke, 299-309. Hamburg: Rowohlt.

Keupp, Heiner and Renate Höfer, ed. 1997. Identitätsarbeit heute. Klassische und aktuelle Perspektiven der Identitätsforschung. Frankfurt/M.: Suhrkamp.

Keupp, Heiner, Thomas Ahbe, Thomas, Wolfgang Gmür, Renate Höfer, Beate Mitzscherlich Beate, Wolfgang Kraus, and Florian Straus. 2006 Identitätskonstruktionen. Das Patchwork der Identitäten in der Spätmoderne. Reinbek bei Hamburg: Rowohlt

Kmec, Sonja. 2007. Von Identitäten und Identifikationen. Forum für Politik, Gesellschaft und Kultur in Luxemburg 271: Lëtzebuerg?, Luxembourg, 39-41.

Krappmann, Lothar. 2005. Soziologische Dimensionen der Identität. Strukturelle Bedingungen für die Teilnahme an Interaktionsprozessen. Stuttgart: Klett-Cotta.

Lahire, Bernhard. 1998. L'homme pluriel. Les ressorts de l'action. Paris: Nathan. Lamnek, Siegfried. 2005. Qualitative Sozialforschung. Lehrbuch. Weinheim: Beltz. Luckmann, Thomas. 2007. Lebenswelt, Identität und Gesellschaft. Konstanz, UVK Verlagsgesellschaft. 
Lüsebrink, Hans-Jürgen. 2005. Interkulturelle Kommunikation. Interaktion, Fremdwahrnehmung, Kulturtransfer. Weimar: Metzler.

MacClancy, Jeremy. 2004. Food, Identity, Identification. In Researching food habits. Methods and problems, ed. Helen MacBeth and Jeremy MacClancy, 63-73. Oxford \& New York: Berghahn Books.

Mayring, Philipp. 2002. Einführung in die qualitative Sozialforschung. Weinheim: Beltz.

Meuser, Michael and Ulrike Nagel 2005. ExpertInneninterviews - vielfach erprobt, wenig bedacht. Ein Beitrag zur qualitativen Methodendiskussion. In Das Experteninterview. Theorie, Methode, Anwendung, ed. Alexander Bogner, Beate Littig and Wolfgang Menz, 71-93.Wiesbaden: VS Verlag.

Meyran, Régis. 2008. Le mythe de l'identité nationale. Paris: Berg International.

Niethammer, Lutz. 2000. Kollektive Identität. Heinliche Quellen einer unheimlichen Konjunktur. Reinbek bei Hamburg: Rowohlt.

Ricoeur, Paul. 1990. Soi-même comme un autre. Paris: Le Seuil.

Rosa, Hartmut. 2007. Identität. In Handbuch interkulturelle Kommunikation und Kompetenz. Grundbegriffe - Theorien - Anwendungsfelder, ed. Jürgen Straub and Arne Weidemann. Stuttgart: J. B. Metzler.

Ruano-Borbolan, Jean-Claude. 1998. L’identité. L'individu, le groupe, la société. Auxerre: Sciences Humaines.

Sennett, Richard. 1996. Etwas ist faul in der Stadt. Die Zeit $N^{\circ} 5$ (26th January): 47-48.

Statec. 2007. Luxemburg in Zahlen. Luxemburg.

Straub, Jürgen. 2004. Identität. In Handbuch der Kulturwissenschaften. Grundlagen und Schlüsselbegriffe, ed. Friedrich Jaeger and Burkhard Liebsch. Stuttgart: J. B. Metzler.

Straub, Jürgen and Joachim Renn, ed. 2002. Transitorische Identität. Der Prozesscharakter des modernen Selbst. Frankfurt/M.: Campus.

Straub, Jürgen. 1998. Personale und kollektive Identität. In Identitäten, ed. Aleida Assmann and Heidrun Friese. Frankfurt/M.: Suhrkamp.

Straus, Florian and Renate Höfer. 1997. Entwicklungslinien alltäglicher Identitätsarbeit In Identitätsarbeit heute. Klasssische und aktuelle Perspektiven der Identitätsforschung, ed. Heiner Keupp and Renate Höfer, 270-307. Frankfurt/M.: Suhrkamp.

Vester, Michael, Peter Von Oertzen, Heiko Geiling, Thomas Hermann and Dagmer Müller. 2001. Soziale Milieus im gesellschaftlichen Strukturwandel. Zwischen Integration und Ausgrenzung. Frankfurt/M.: Suhrkamp.

Weinreich, Peter and Wendy Saunderson, ed. 2003. Analysing Identities. CrossCultural, Societal and Clinical Contexts. London: Routledge.

Weischer, Christoph. 2007, 207-209 Sozialforschung. Weinheim: Beltz.

Willems, Helmut and Paul Milmeister. 2008. Migration und Integration. In Das politische System Luxemburg. Eine Einführung, ed. Wolfgang H. Lorig and Mario Hirsch, 62-92. Wiesbaden: VS Verlag. 
Zahlen, Paul. 2008. Arbeitsmarktpolitik. In Das politische System Luxemburg. Eine Einführung, ed. Wolfgang H. Lorig and Mario Hirsch, 253-285. Wiesbaden: VS Verlag. 


\section{Aus:}

\section{IPSE (ed.): Doing Identity in Luxembourg. Subjective Appropriations - Institutional Attributions - Socio-Cultural Milieus. Bielefeld, transcript, 2011.}

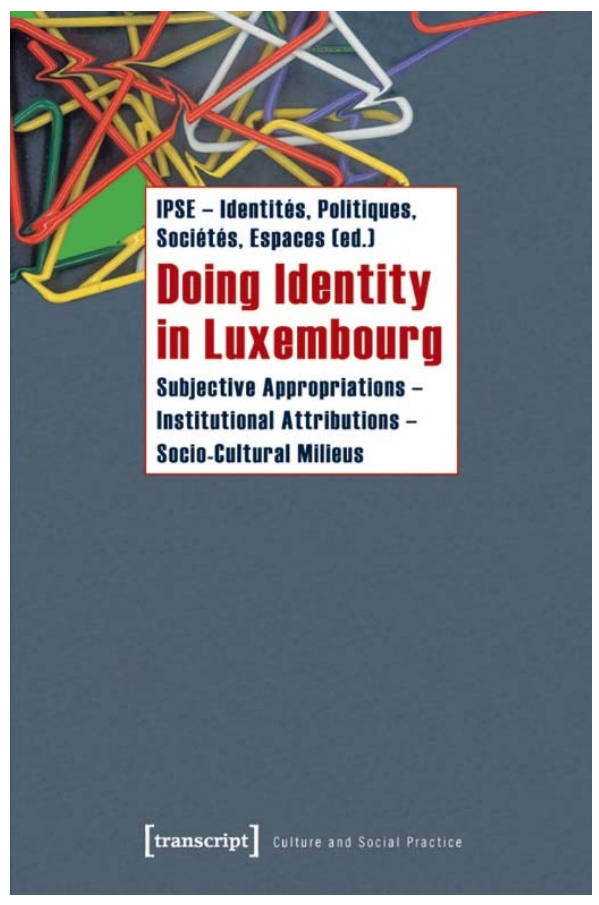

This empirical study provides insights about a society that has hitherto largely eluded scientific investigation and observes the processes of identity construction in globalised conditions. The interdisciplinary team of authors exposes the processes of subjective appropriations and institutional attributions at work in the fields of languages, spaces, perceptions of self and others as well as everyday cultures, and identifies for the first time socio-cultural milieus in the Grand Duchy. The findings of the three-year research project uncover the ambivalences and dynamics of a multicultural and multilingual society. 


\section{Content}

I. Preface $\mid 7$

Rachel Reckinger, Christian Schulz, Christian Wille

2. Researching Identity Constructions $\mid 11$

Rachel Reckinger, Christian Wille

2.1 A theoretical-conceptional approach to identities $\mid 11$

2.2 Methodology and Interdisciplinary Collaboration | 24

2.3 References | 35

3. Socio-Cultural Milieus in Luxembourg | 39

Wilhelm Amann, Fernand Fehlen, Georg Mein

3.1 Changing Social Structures. From the vertically orientated concept of stratification to the horizontally diversified milieu landscape 39

3.2 Profiles of Socio-Cultural Milieus in Luxemburg | 50

3.3 Final remark $\mid 62$

3.3 References $\mid 62$

4. Languages and Identities $\mid 6_{5}$

Peter Gilles, Sebastian Sefla, Heinz Sieburg, Melanie Wagner

4.1 Introduction: Germanic/Romance Diglossia | 65

4.2 Key Survey Results Concerning the Linguistic Situation | 68

4.3 Controversies in Readers' Letters concerning the Linguistic Situation | 81

4.4 'Linguistic Landscape': Public Signage and Multilingualism | 93

4.5 Conclusion: Linguistic Polynomia as an Opportunity $\mid 103$

4.6 References $\mid 104$

5. Spaces and Identities $\mid 107$

Marion Colas-Blaise, Sylvie Freyermuth, Sonja Kmec,

Gian Maria Tore, Christian Schulz

5.1 Introduction: Geographic Discourses and Tourism Practice | 107

5.2 Between Seduction and Reality: Luxembourg City and its Discourses $\mid 110$

5.3 Representing and Revaluating the City: the Geo-Graphy and Visual Identity of Luxembourg City $\mid 120$ 
5.4 Between National Unity and Regional Individualism 'Sways the Heart of Luxembourg' | 125

5.5 The Image of Luxembourg as a 'Melting Pot' | 133

5.6 The "Greater Region" - Spatial Constructions between Desire and Reality | 144

5.7 Conclusion: Spatial Identities - Multiple Readings?| 155

5.8 References 158

6. Images and Identities $\mid 165$

Wilhelm Amann, Viviane Bourg, Paul Dell, Fabienne Lentz, Paul Di Felice, Sebastian Reddeker

6.1 Images of Nations as 'Interdiscourses'. Preliminary Theoretical Reflections on the Relation of 'Images and Identities': The Case of Luxembourg | 165

6.2 Symbolisms in the Media-Based Perceptions of Self and Others of Luxembourg $\mid 168$

6.3 The Superjhemp Saga - an Ideal Projection Screen 179

6.4 Collective Symbols and (New) Identity Options in Luxembourg's Advertising $\mid 190$

6.5 Decontextualising and Deconstructing Representations of Identity: an Analysis of the Works of Seven Photographers | 202

6.6 The Representation of Italian Immigrants in the Exhibition Catalogue Retour de Babel | 216

6.7 Conclusions: National Identities in a Post-national Age?|225

6.8 References $\mid 226$

\section{Everyday Cultures and Identities $\mid 233$}

Christel Baltes-Löhr, Agnes Prüm, Rachel Reckinger, Christian Wille

7.1 Introduction: On the Reciprocal Relevance of Everyday Cultures and Identity Constructions | 233

7.2 Permanent Performances: Gender in Motion | 238

7.3 'Good' Food. Oscillation between Political Concept and Individual Everyday Practice | 255

7.4 Cross-Border Workers as Familiar Strangers | 271

7.5 Conclusions: Identities and Ambivalences of Everyday Cultures $\mid 283$

7.6 References $\mid 285$

8. Identity Constructions in Luxembourg | 291

Rachel Reckinger, Christian Wille, Christian Schulz

Authors | 295 